\title{
THE YOUTH FACTOR IN ZIMBABWE'S 2013 HARMONISED ELECTIONS
}

\author{
Obert Hodzi \\ Obert Hodzi is a PhD candidate in the Department of Political Science, \\ Lingnan University, Hong Kong. \\ e-mail: ohodzi@gmail.com
}

\begin{abstract}
The youth in Zimbabwe have often been described as disenfranchised, corruptible and susceptible to manipulation by politicians. This narrative assumes that the youth are a homogenous group, uniform in their grievances and consensual about strategies to resolve them. Analysing the case of youth participation in the 2013 harmonised elections in Zimbabwe, this article challenges that assumption by arguing that the youth are polarised and struggling to articulate a national objective that might be able to shift the country's political discourse. It contends that the majority of Zimbabwean youth act as loosely affiliated individuals seeking personal rather than group benefits. At the same time, by assessing the engagement of youth within political parties either as supporters or officials, the article further argues that the structural dynamics of these political parties deny the youth agency and make them conform. It therefore concludes that participation by the youth in the 2013 elections was mainly driven by individual interests rather than collective grievances or political identity.
\end{abstract}

\section{INTRODUCTION}

The political discourse related to the youth in Zimbabwe and across the African continent is dominated by narratives of disenfranchised and corruptible young people who 'are unwittingly conscripted into armed struggles, used to settle political scores and are exposed to various negative media that erodes their positive heritage' (African Union 2011, p vii). Yet experiences in Tunisia, Libya and Egypt seem to contradict that narrative, expounding the agency of the youth and hailing their efforts in organising and participating in revolutions that changed the political trajectory of their countries. 
Despite being contradictory, both narratives assume that the youth are a distinct collective group, uniform in their grievances and consensual in strategies to resolve them. Analysing the case of youth participation in the 2013 harmonised elections in Zimbabwe, this article challenges that assumption. It argues that the political terrain in Zimbabwe is characterised by youth that are polarised and struggling to articulate a national objective that can shift the country's political discourse. It contends that the majority of Zimbabwean youth act as individuals, loosely affiliated and seeking personal rather than group benefits. At the same time, by assessing the engagement of youth within political parties either as supporters or officials, the article also argues that the structural dynamics of these political parties deny the youth agency and demands that they conform.

\section{THEORETICAL FRAMEWORK: SELF-INTEREST AND PERCEIVED IDENTITY}

As its theoretical framework, this article assumes that the individual is the basic agent in society and that given options during elections the individual will choose the one with the highest expected utility. However, such options are not limited to the post-election period but also exist in the pre-election period. For instance, a youth may decide to support a political party or election candidate not on the basis of what he or she stands to gain (self-interest) if the candidate or political party wins the election but on the immediate benefits that might be gained from support in the pre-election period.

These assumptions reflect the Rational Actor Theory, which 'adopts a methodological individualist position and attempts to explain all social phenomena in terms of the rational calculations made by self-interested individuals' (Scott 2000, p 136) and therefore argues that 'individual behaviour is motivated by selfinterest, utility maximisation, or more simply put, goal fulfilment' (Petrecca 1991, p 289). On its own, however, the rational actor theory fails to account adequately for individual voting behaviour because individuals do not usually possess extensive information about the different options they are offered, let alone fully comprehend the consequences of the choices they make during an election.

Without extensive information about the promises made during election campaigns and whether these will actually be fulfilled if the party or candidate wins the election and about how voting for a certain candidate or political party will benefit them, individuals cannot be fully rational in their choices. Because of this lack of information, individuals may engage in political activities such as elections on the basis of their 'perception of self in relation to others; this perception effectively delineates and sets the domain of choice options perceived as available to an actor, both in an empirical and a moral sense' (Monroe \& Maher 1995, p 12). 
This leads young people to pursue 'self-mastery', that is, 'the conscious attempt by the individual to define and control his or her behaviour and identity' (Hodgkinson 2013, p 866). In essence, elections become a springboard used by individuals to define their identity and assert their interests; hence, apart from acting in self-interest, individuals may participate in elections on the premise of their perceived identity in relation to others and also on the basis of how others perceive them - their identity being defined through their self-interest. In this respect, self-interest, which is based on one's identity in relation to others, will be used to explain the participation of the youth in the 2013 elections in Zimbabwe.

\section{DECONSTRUCTING THE YOUTH CONCEPT IN ZIMBABWE}

'Youth' is a complex social construct that is difficult to define (Hodgkinson 2013, $\mathrm{p} 866$ ). There seems to be no consensus even with regard to the age group referred to. For instance, the United Nations (2007; see also World Bank 2007) defines a youth as an individual aged between 15 and 24 years; for the African Union (2006) and the Zimbabwean government (2013) it is 15 to 35 but for the Movement for Democratic Change led by Morgan Tsvangirai (MDC-T) the range is between 16 and 35 (MDC 2011). In the Zimbabwe African National Union-Patriotic Front (Zanu-PF) the youth are between the ages of 15 and 30.

To avoid complicated generalisations and bloated research this article inclines towards the African Union and the government of Zimbabwe's definition of youth as any individual aged between 15 and 35 years of age, with a deliberate focus on young people of voting age, that is, those above the age of 18 . This not only provides a logical and convenient conceptualisation of youth, it also helps to streamline and nuance the study.

Youth can also be defined in terms of social status and level of adulthood. It can be argued that due to poverty, bad governance and failed economies many people 'have had to delay their entry into adulthood: they feel excluded and powerless, and struggle to survive [independently]' (Abbink 2005, p 6). Acinda Honwana (2012) describes such people as being in a state of 'waithood' between childhood and adulthood and not able to participate fully in their governance.

This situation is common in Zimbabwe, where it is possible to find children under the age of 14 heading families (children with adult roles) and people above the age of 35 (adults with youth characteristics) who, as Abbink (2005, pp 6-7) writes,

have not completed their education, have no job, are not in a position to raise a family, [and] indeed sociologically resembling the 
biologically younger people with whom they share a life defined by poverty and deprivation.

From this, it is clear that the concept of the youth cohort is not simple; the sociopolitical and economic context in Zimbabwe compels the youth to be characterised not just in terms of age but also in terms of their state of 'waithood'.

The discourse of the youth and elections in Zimbabwe cannot be separated from the socio-political and economic grievances that have come to define age groups. With $72 \%$ of the people living under the national poverty line (World Food Program 2012), poor service delivery, a failing economy and political disenfranchisement emanating from elitist politics and a civil society separated from the general populace (Masunungure 2011, p 126), children, the youth and adults alike find themselves confronted by the same issues.

The youth are by no means a homogenous group: the socio-political and economic concerns differ among professionals, rural youth, urban youth, unemployed youth (rural or urban) and those in the diaspora. For instance, while the majority of urban youth were concerned with service delivery, access to financial loans and secure employment, the youth in the diaspora were concerned with the state of the economy and their right to vote.

These factors affected the way young people of voting age interacted with the 2013 electoral process.

\section{CENSUS AND VOTERS' ROLL STATISTICS}

The population of Zimbabwe is approximately 12973808 (ZimStats 2012). The adult population (18+ years of age) is about 6647779 , constituting $51.23 \%$ of the country's total population. The youth (18-35 years) population is around 3572 987, which is $27.54 \%$ of the total population and $53.74 \%$ of the country's adult voting population. Based on these figures, the youth are a significant constituency for national agenda-setting, electoral mobilisation and political participation. But the state of the voters' roll, if it is to be regarded as a standard for gauging how politically engaged the youth in Zimbabwe are, suggests otherwise. According to the Research and Advocacy Unit's (RAU) audit report on the 2013 voters' roll, only $8.87 \%$ of youths in the age group 18-19 were registered to vote; $19.55 \%$ of those between 20 and 24 and 51.69\% of those between 25 and 29. According to the same report, the number of registered voters in the age group 30-34 years exceeded the population in that age group by $6.12 \%: 106.12 \%$ were registered as voters. What are the reasons for this 'under-registration' in the 18-29 year group and the 'over-registration' in the 30-34 age group? 
Several explanations have been given. The first is that the over-registration in the 30-34 age group could be explained by the excessive numbers of people within that age group who emigrated from Zimbabwe to neighbouring countries because of economic hardship and the deceased, whose names were not deleted from the voters' roll (Merz 2013). Since their names still appear on the voters' roll the population figures recorded in the 2012 census were lower than the number of registered voters. Secondly, Transparency International Zimbabwe (TI-Z 2013) reported that 'there were over 300000 duplicated names on the voters' roll'. In addition, complaints of voters' roll manipulation were raised on several occasions - people who had never registered as voters found their names on the roll. The under-registration of the 18-29 age group was, to a large extent, caused by the chaotic registration process conducted by the Zimbabwe Electoral Commission (ZEC) and will be discussed below.

\section{VOTER REGISTRATION: THE YOUTH AS ‘SWING VOTERS’}

The youth in Zimbabwe represent an important constituency for mobilisation by political parties and senior politicians because the majority were regarded in the 2013 election as 'first-time-voters', inexperienced in the electoral process and therefore 'swing' voters worth competing over. Because of this perception the youth became the target of political party mobilisation campaigns and of non-governmental organisations (NGOs) that implemented voter education and registration campaigns.

The media and political analysts reiterated the significance of capturing the youth vote, identifying them as the ultimate determinants of the victor in the July 2013 elections (Fox News 2013). Given the perceived centrality of the youth vote, voter education and registration became the subject of a political contest among the major political parties. Central to that struggle was the accreditation of civil society organisations to provide voter education alongside that offered by the ZEC. With significant financial resources compared to those of the ZEC, civil society organisations were widely seen as aligned to the MDC-T and therefore likely to use voter education as a political campaign and youth mobilisation exercise for that party at the expense of Zanu-PF.

In terms of Section $40 \mathrm{~B}$ of the Electoral Act (Chapter 2:13), the ZEC has the primary responsibility to provide voter education. Any other organisations wishing to provide voter education and information on voter registration must be registered with and accredited by the ZEC. The accreditation process for NGOs was fraught with challenges. First, the ZEC advertised for organisations to apply weeks before the elections and then imposed stringent conditions such as disclosure of funding sources, conditions with which most organisations were 
unwilling to comply. The main reason for that is that most organisations were funded by foreign donors who preferred anonymity, partly for fear of being targeted by state security agents and mainly because foreign funding for voter education was outlawed unless the funds were directed to the ZEC (Electoral Act chapter 2:13, s 40F).

The effect was to delay the accreditation process as organisations sought ways of meeting the ZEC's requirements without disclosing their funding sources. By the time the organisations were accredited the political parties had already started campaigning - shrinking their operation space and rendering their efforts futile. As a result, several organisations conducted voter education illegally under the guise of civic education, which is not regulated. The risk of arrest was significant. For instance, the Election Resource Centre, a local non-governmental organisation, was charged by the Zimbabwe Republic Police (ZRP) with conducting voter education without the ZEC's authorisation in contravention of section 40 (C))1) (g) of the Electoral Act (Amnesty International 2013); other organisations, such as the Zimbabwe Election Support Network (ZESN) and the Zimbabwe Human Rights Association (ZimRights), were raided by the police, who alleged that they were engaging in illegal voter education and mobilisation campaigns. This severely affected their operations.

Nevertheless, two voter registration exercises were conducted by the ZEC in the run-up to the harmonised elections of 31 July 2013. The first was conducted between 29 April and 19 May. The second took place between 10 June and 10 July 2013 after the signing of the Constitution of Zimbabwe Amendment (No 20) Bill into law on 22 May 2013. The new Constitution provided for a mandatory 30-day voter registration exercise before the elections were held (Sixth Schedule, Part 3, Article 6(3) of the Constitution of Zimbabwe Amendment (No. 20) Act 2013). However due to a lack of funding, the ZEC

deployed only two people per ward (some of them geographically huge) to undertake the exercise. The poor delivery of voter education was evidenced by the 56,627 voters who spoilt the ballots out of the $3,259,454$ who voted.

ZHRC 2014, p 9

With limited support from civil society organisations both voter registration exercises were inadequate. The Common Market for Eastern and Southern Africa (COMESA 2013) Observer Mission observed that 'comprehensive voter education may have been constrained by the limited time available before the holding of polls, in order to adequately educate citizens on the electoral reforms brought about by the new Constitution'. This view was reiterated by the African 
Union Election Observation Mission (AUEOM 2013, p 13), which concluded that 'thousands more Zimbabweans were unable to register due to the expiry of the 30 day prescription period'.

Youth within the 18-29 age group were most affected by voter registration requirements such as production of proof of residence and the limited time allowed for registration. Proof of residence included utility bills, tenants' agreements and title deeds, so young people who neither rented nor owned property found it difficult to register. As a result,

hundreds of potential voters were turned away for not possessing relevant documents, in particular proof of residence which is required to register as a voter. In addition, aliens were denied registration even though they possessed Zimbabwean identity documents.

Hodzi 2013

The Zimbabwe Human Rights Commission (ZHRC 2014, p 8) also noted that "the mobile voter registration exercise failed to facilitate for a majority of "aliens" to get documents to enable them to register as voters provided for by the new constitution'. When the conditions were relaxed and affidavits accepted as sufficient proof of residence the Registrar-General Office's personnel conducting the registration exercise were overwhelmed by the turnout and few people were registered by the time the registration process ended.

These challenges raised concerns among human rights activists and political parties such as MDC-T, who complained that the registrar-general had neglected areas known to be non-Zanu-PF strongholds in an effort to systematically disenfranchise potential opposition supporters from registering as voters (Hodzi 2013).

The ZESN (2013) suggested that 'urban voters had systematically been denied the opportunity to register to vote. A total of $99.97 \%$ of rural voters were registered while only $67.94 \%$ of urban voters were registered.' It therefore concluded that more than 750000 eligible urban voters were not registered, compared to about 1200 eligible rural voters. Essentially, the youth in urban areas had been disenfranchised because of their perceived identity as potential supporters of MDC-T. The youth in rural areas were regarded as potential Zanu-PF supporters.

\section{URBAN YOUTH DEFIANCE}

Regardless of the structural challenges imposed on voter registration, youth organisations and individual activists devised web-based platforms and made use of social media to encourage the youth to register, check their names on the 
voters' roll and eventually go out and vote. For instance, a consortium of youth organisations launched a first-time voters' registration campaign.

The First Time Voter Campaign, branded X-1 Generation, was targeted at youth between 18 and 35 years of age, most of whom would vote for the first time in the 2013 election, to encourage them to participate effectively in the electoral process. It was coordinated by the Election Resource Centre (ERC) and included organisations such as the Youth Forum. Through social networking sites and private radio stations the campaign provided information about voter registration centres, required documents and other relevant information which was otherwise difficult for the youth to obtain. Although the campaign's message was aimed at young first-time voters it also resonated well with older potential voters who had not participated in previous elections.

Internet-based platforms were also used. These included platforms such as the www.myzimvote.com and www.zimvoices.co.zw, which enabled Zimbabwean youth to check the voters' roll for such information as their names, their polling station, ward and constituency. This provided a reprieve for mainly urban youth who could not verify with the Registrar General's Office due to long queues and the bureaucracy involved. Crowd-sourcing platforms such as www. zimelections2013.com provided the youth with the opportunity to share their observations of the electoral environment through social networks, voice calls and SMS.

Most of the platforms were initiatives of politically unaffiliated youth who sought to circumvent the structural challenges that inhibited them from registering as voters, verifying their voter registration details and obtaining essential information about where they should vote and their nearest polling station. But the challenge was lack of coordination, duplication of effort and the concentration on urban and semi-urban youth with access to the internet. Youth in rural areas were largely neglected.

As a result, promoters of the various initiatives competed for the attention of the youth, rendering their efforts less effective. Furthermore, because of their focus on urban and semi-urban youth and perceived Western funding the campaigns were viewed by state security agents and state media as pro-MDC-T (Kuvirimirwa 2013). To curtail their impact the government banned the sending of bulk SMSs and increased its monitoring of the internet (MISA-Zimbabwe 2013).

To enhance their mobilisation of first time voters, political parties and youth organisations engaged in door-to-door voter mobilisation campaigns, which, in turn, were banned, this time by the Zimbabwe Republic Police Officer Commanding Harare Sub-Region (Zhangazha 2013). Despite the ban Zanu-PF enlisted its youth, affiliated students, the Women's League and war veterans to implement its door-to-door voter mobilisation campaign across the country (The 
Daily News 2013). While these organisations faced no hindrance from the police, MDC-T campaign volunteers who attempted to do the same were arrested for impersonating government officials and for conducting voter education without the authorisation of the ZEC.

In rural areas Zanu-PF aggressively used the traditional leadership structures to ensure maximum registration; the focus was not just on the youth but on the whole adult population. In addition, the ZEC focused more on rural communities during the registration process, arguing that the majority of the population lived there. As a result, the registration rate in purely rural constituencies, from which Zanu-PF is believed to draw the bulk of its support, was considerably higher (94\%) than that in purely urban constituencies (74\%), from which the MDC formations draw most of their support (RAU 2013, p 7).

In a statement published by ZESN (2013) at the end of the ZEC's mobile voter registration and voters' roll inspection exercise the organisation suggested that 'the 3 days spent per ward by the teams was inadequate given the huge turnout of potential voters in various parts of the country, especially urban areas'. Calling for the ZEC to extend the registration exercise, the ZESN argued that there was

under-registration of eligible voters in urban wards with approximately 750000 missing urban voters and under-registration of youth voters in urban and rural wards with approximately 400000 missing voters ... these youth voters [under 25] are only $5 \%$ of registered voters compared to 20\% in the Zambian election held in 2011.

ZESN 12 July 2013

The ZEC refused to extend the exercise and the net effect was that a significant proportion of the youth, especially first-time-would-be-voters, failed to register and remained outside the electoral processes.

\section{YOUTH ENGAGEMENT IN FORMAL POLITICS}

Youth participation in Zimbabwean political parties is difficult to determine because there is a lack of age-disaggregated data in political party membership registers. However, political party structures follow the same vertical structure of leadership and decision-making. 'The structures are the framework of committees and offices that organise the party's ranks' (Wilkins 2013, p 891). In almost all major political parties in Zimbabwe the low-level workers and volunteers tend to be the youth, while the leadership is dominated by older people. In most cases the youth are confined to party youth leagues or their equivalents. Even in the opposition political parties, such as MDC-T, youth appear to be excluded from 
mainstream politics, confined to youth wings and left out of decision-making and agenda-setting processes in a move that Maureen Kademaunga (2011, p 157), a youth activist and member of the MDC-T National Youth Assembly, has described as 'institutionalised marginalisation'.

They have been disenfranchised from mainstream politics at all levels, from the party political level to the national electoral level. They have largely been disregarded in electoral calculations because they are viewed as an insignificant group in terms of decision-making processes.

She further argues that

the structure that you find in all of Zimbabwe's political parties has what is called a youth wing ... this is a strategy to keep young people content and yet far from actual decision making structures; that is exclusion by inclusion because the youth wing and the women's wing are sub and all decisions are made by the main wing.

Interview, 6 January 2013

Another activist described the youth wings of political parties as mere support bases for senior politicians (Interview, Gladys Hlatywayo, 19 December 2013). The main wing that Maureen Kademaunga referred to is the National Executive Council in the case of MDC-T and the Politburo in Zanu-PF.

The youth assemblies are considered by mainstream politicians as a reservoir of foot soldiers used to mobilise support for the political parties (interview Gladys Hlatwayo). This is made possible by the fact that, 'almost all of the MDC-T's youth activists are unemployed and most have never known formal employment (Wilkins 2013, p 891). The same is true of Zanu-PF's youth activists. In cases of internal political dissent within political parties these youth assemblies have been used to legitimise the leadership and its political decisions. For instance, when the MDC-T highest decision-making body resolved that its National Youth Leader, Solomon Madzore, should stand uncontested for the Dzivarasekwa constituency seat in the 2013 elections, the party's national youth spokesperson said:

Who will stand in Dzivarasekwa is a national resolution. The youth are the eyes of the party and we agreed as a party ... I am simply announcing the resolution. Who are you kupikisa Save [who are you to go against Morgan Tsvangirai]? 
Similarly, the Zanu-PF Youth League has, on numerous occasions, endorsed Robert Mugabe's candidature and has rarely offered opinions that differ from those of the Politburo.

Youth exclusion from mainstream politics was most prevalent in the selection of party candidates for the 2013 elections. In the MDC-T candidates were selected at National Executive level, which determined that some constituencies would hold primary elections while others would hold confirmation polls for incumbent members of Parliament. The rationale behind this arrangement was twofold: to avoid internal conflicts resulting from primary elections and to protect senior politicians from losing primary elections.

However, after members complained, primary elections were eventually conducted in almost all the country's constituencies. Zanu-PF, on the other hand, delayed primary elections until the week before the national elections and allegations of vote-buying, rigging and a chaotic voting process dominated the party's primary election narrative. In both parties the Politburo (Zanu-PF) and the National Executive Council (MDC-T) dominated the determination of the final candidate list, further alienating the youth from active participation as candidates. Demands for a constitutionally mandatory youth quota along the lines of the women's quota were largely ignored by the leaders of both major parties.

The new Constitution provides for a hybrid system of first-past-the-post (FPTP) and proportional representation (PR) system. FPTP is applicable to the 210 National Assembly seats, while the 80 members of Senate and the 60 seats reserved for women in the National Assembly and the provincial councils are filled by means of a PR system. Invariably,

[t]he proportion of votes each party receives in the National Assembly election in each province will determine the number of seats that party receives in the Senate, in the women's list for the National Assembly and in the Provincial Council.

African Union Commission 2013, p 9

The effect of these provisions is that although there was a quota for women candidates there was no quota for the youth, forcing them to contest against veteran politicians for nominations for National Assembly seats. Because of the importance of the National Assembly all parties fielded their strongest candidates, which largely excluded the youth. In most cases, the youth were relegated to constituencies where they had no chance of winning. For instance, the majority of youth candidates in Zanu-PF were fielded in urban areas, where their chances of winning against MDC-T candidates were slim.

The primary elections and selection of party candidates in both the MDC-T and Zanu-PF was mostly characterised by internal violence, imposition of 
candidates by the leadership and patronage, further disenfranchising the youth, who largely lack the financial and political muscle of older politicians. There were a few notable exceptions. Youth candidates who stood for National Assembly seats included Varaidzo Carol Mupunga (25), Zanu-PF candidate for Harare West, and Acie Lumumba (25), Zanu-PF candidate for Hatfield. Other youths, such as Tendai Wenyika (28), Zanu-PF; Maureen Kademaunga (28), MDC -T and Tionei Melody Dziva (29), Zanu-PF, were on their parties' proportional representation women's quota list.

However, as mentioned above, most of these young people stood in areas where their parties had no chances of winning. None of the Zanu-PF youth candidates who stood in urban areas and none of the MDC-T youth candidates who stood in rural constituencies won a seat.

In reality, none of the parties seems interested in having young people as active participants although they are happy to have their backing as voters, vigilantes and campaigners - an attitude that is bound to limit the enthusiasm of young people for political participation (ActionAid Denmark 2013, p 22).

The situation is even more precarious for the youth in underdeveloped rural areas and areas outside of major urban centres; in most cases they have been excluded from the democratic reform agenda, which is dominated by elite activists and middle-class co-opted youths in Harare. Furthermore, the nature of politics within political parties in Zimbabwe does not 'develop critical political minds that could challenge their policies and ideologies' (Honwana 2013, p 112). According to Gladys Hlatywayo, Executive Director of the Zimbabwe Civic Education Trust (ZIMCET), the lack of financial independence of young people in Zimbabwe makes them and party youth wings subject to the will of political 'godfathers' who provide them with direction and resources (interview 19 December 2013). In Zanu-PF 'the dominant power structure and patronage networks are rigid, conservative and often vertically organised' (Abbink 2005, p 11). The situation in MDC-T is similar. Since its inception in the late 1990s the MDC-T has been the only viable alternative for youths who could not join Zanu-PF, as the older generation clung to power. But even so, increased disenfranchisement of the youth in the MDC-T and concerns over increased centralisation of power by Morgan Tsvangirai and his allies within the party, which resulted in the split in the MDC-T in April 2014, suggest that the MDC-T has gradually gravitated towards a situation where

established systems of patronage, engendered by new but often inconsistent demands for 'good governance' and political accountability by donor countries and international organisations, were redefined, allowing many old-style elites (as well as new ones) to reinstate or reshape neo-patrimonial rule 
As stated above, this manifested itself in the imposition of candidates, structural exclusion of the youth by outlawing primary elections in several constituencies and a lack of political and financial support for those young people who stood for election. The result was that young people who stood for election fared badly compared to their older compatriots.

\section{POLITICAL CAMPAIGNS AND YOUTH CLIENTELISM}

The economic hardships that resulted from the land reform programme in 2000 and from years of corruption, poor economic performance and decaying infrastructure, persistent strikes by teachers and doctors, poor health and service delivery as well as political repression left the country's population, particularly the youth, disenchanted.

The once-vibrant student movement was dissipated by infiltration by state agents and interference by political parties and ruthlessly crushed by the police. With no avenues for voicing dissent many left Zimbabwe for South Africa, Botswana, the United Kingdom and other countries. The cumulative effect of these socio-political and economic problems was that the focus of citizens moved from political issues such as elections to economic survival. As a result, elections were characterised by increased voter apathy, particularly from the youth. Accordingly, political parties were confronted with the need to restore confidence in the electoral process and encourage the youth to vote, while providing solutions to the myriad challenges the youth faced.

To a large extent, the political campaign in the 2013 election was dominated by grandiose, yet vague, promises of millions of jobs and economic empowerment projects for the youth. The MDC-T manifesto promised a million jobs by 2018 and Zanu-PF promised to establish a US\$5 900498 National Presidential Youth Initiative. According to the Zanu-PF manifesto people between the ages of 18 and 35 constituted $61 \%$ of the eligible voters in Zimbabwe; therefore it pledged to protect the youth from 'external political, cultural and information manipulation which, if left unchecked, often results in the youth becoming politically apathetic or misguided' (Zanu-PF 2013, p 26). Again, the assumption was that the youth are supposed to be protected rather than allowed to exercise their agency.

The party further promised to establish a new youth policy that would institute a $25 \%$ quota threshold for youth participation in all sectors of the government and economy. Yet still, the message from the political parties and their manifestos failed to articulate the economic and social problems the youth were facing and the political message was often overshadowed by smear campaigns. Hence, it can be argued that 
[t]hese economic and social considerations were set out hazily [in political party programmes] with general statements ... and without any analysis of the origin of this situation, systematic critiques of past options, or concrete proposals to address socioeconomic demands in depth.

Hibou, Meddeb \& Mohammed 2011, p 92

The generalised and abstract statements made at political rallies, which failed to cater for the youth because of their focus on economic empowerment or creation of jobs, without effectively articulating how these would be attained and what role the youth would play in resolving these problems and the negotiated settlements between political parties in the run-up to the constitutional referendum left the youth feeling neglected by parties that were more concerned with securing political power than with addressing their problems.

The failure of the parties to address issues of the diaspora vote and the chaotic voter registration and voter education processes made the youth sceptical about the election process and unsure of how different it was going to be from previous ones. Because the campaigns failed to articulate youth issues they also failed to ignite the interest of the youth in participating in the elections.

Coupled with a non-responsive political message from political parties was the commodification of youth electoral participation by most NGOs. Youth participation projects organised by NGOs were predominantly donor funded, with most of the funding released a few months before the elections, posing serious challenges to the quality of project implementation.

Of particular significance was the fact that as soon as the NGOs realised that the donor community was focusing on the youth, numerous youth-targeted projects emerged, while the number of associations claiming to target the youth and mobilising them to participate in the July 2013 elections surged. The majority claimed to provide platforms from which young people could articulate their views and express their demands to political parties and the level of duplication and concentration of activities in urban areas was tremendous.

According to Eldred Masunungure (2011, p 127),

the sad truth about Zimbabwe's civil society is what may be characterised as a high, if not overdeveloped, sense of 'organisational sovereignty', by which I mean oversensitivity to organisational turf and the felt need to defend such territory. This organisational psychology militates against effective and sustained collaboration among civil society organisations as each wants to do its own thing in its own way with little 'interference' from others. 
The result was that donor-funded projects were widely regarded as lacking transparency and the youth who participated were usually members of other civic organisations and political parties such as the MDC-T. Consequently, neither the civic organisations nor their youth-targeted projects were anchored in 'domestic constituencies' (Masunungure 2011, p 126), who, in this case, were the youth. Most of the participants would get per diems, hotel accommodation and transport cost reimbursements. Inevitably, the youth who were excluded from these campaigns saw them as a means of legitimising the abuse of donor funds, hence their participation was half-hearted and the projects had little impact. For these reasons, particularly the commodification of political processes, the youth in Zimbabwe lacked coordination and a unified voice. Youth organisations and NGOs sought to maximise funding opportunities offered by Western donors, whilst the ordinary youth sought to gain as much financial and material benefit from the organisations as they could.

\section{YOUTH-POLITICAL PARTY LINKS: COMMODIFICATION OF THE YOUTH VOTE}

The influence of self-interest and the perception of the youth as 'swing voters' is best illustrated by the patron-client relations narrative. In most cases youth links with politicians were mainly based on 'direct material inducements targeted to individuals and small groups of citizens whom politicians know to be highly responsive to such side-payments and willing to surrender their vote for the right price' (Kitschelt \& Wilkinson 2007, p 2).

These material inducements ranged from party regalia to financial loans and employment. For instance, the small emerging youth middle class in Harare and a few other major towns, who were beginning to enjoy the benefits of economic stability under the Government of National Unity, were largely uninterested in voter registration processes and elections and tended to focus on the gains political parties offered in the immediate term. This group of young people was interested in the government's Ukondla/Kurera Youth Fund, an economic empowerment fund established several months before the elections (The Zimbabwean, 3 October 2012; NewsDay, 1 February 2013). The Zanu-PF manifesto also promised to establish a National Presidential Youth Initiative worth almost US\$6-million as one of its key post-election deliverables.

The majority of young people were sceptical about the ability of the future government to implement promises such as improved job opportunities and economic empowerment and sought to take advantage of instant and personal benefits rather than wait for the benefits of long-term policies. According to Kitschelt \& Wilkinson (2007, pp 25, 26): 
Poor people cannot wait for material rewards and therefore prefer targeted hand-outs to the distant benefits of policy change ... poor people may have less education and therefore less capacity to understand and trace the lengthy causal process linking policy changes to personal benefits. This may make them ignore or understate the value of large-scale club or collective goods

Where Zanu-PF could not offer financial resources it offered government jobs to the youth. For instance, despite a government ban on new civil service recruitment, the Zimbabwe National Army and the Ministry of Home Affairs continued to recruit. The then finance minister, Tendai Biti, stated in Parliament that

between January and May 2012 there has been an unlawful increase of about 10000 employees in the Public Service Commission ... the two chief culprits are the Ministry of Defence, which employed 4600 personnel since January 2012, and the Ministry of Home Affairs, which has recruited 1200 personnel without Treasury approval.

NewsDay 2012a

In response, the Minister of Defence, Emerson Munangagwa, argued that the Zimbabwe Defence Force needed to recruit continuously to maintain its strength. However, the majority of those recruited were youths from rural areas who lacked significant employment opportunities and educational qualifications. The army's Chief of General Staff, Major General Martin Chedondo, was quoted by the media as saying 'now that soldiers are being recruited from every village, we want to see a village that will go against national values' (NewsDay 2012b).

The newly-recruited youth played a crucial role in the special voting by the police and army that was widely criticised for being chaotic and susceptible to rigging by Zanu-PF. Instead of being used to perpetrate acts of violence against the populace and perceived supporters of MDC-T, they were allegedly used to rig the elections, first during the special vote and then on election day, when most of those in the army and the police voted again. One local election observer noted trucks bringing soldiers to vote at several polling stations in Mutoko.

The then Minister of Youth Development, Indigenisation and Empowerment, Saviour Kasukuwere, defended his ministry's recruitment of 7000 youths as ward youth officers -5000 more than the number that had been approved by the Treasury, arguing that he needed to recruit at least 15000 youths as part of his ministry's youth development and empowerment drive (Herald 2011). With the looming or imagined threat of losing their jobs if Zanu-PF lost the elections, the employed youth focused on protecting their jobs by obeying the demands of Zanu-PF politicians. 
Unemployed urban youth, who lacked the financial means and options of those in employment also saw the elections as an opportunity for a better future. In addition, there were part-time jobs as party campaigners, free food handouts, allowances for attending meetings and small-scale projects offered by campaigning politicians in their constituencies. These unemployed young people were the focus of the major political parties, whose manifestos contained promises of jobs and economic empowerment.

For the youth in rural areas, largely unemployed and living in grinding poverty, promises of jobs and economic empowerment compelled them to participate in large numbers. Yet the youth in the diaspora, who had supported the economy and their families during the economic difficulties of 2008, were denied the right to vote and were largely excluded from the political processes in the country (Ndlovu 2013).

As the youth positioned themselves within political parties that they believed would satisfy their immediate needs, a disjointed youth movement lacking a national thrust was solidified; consequently, the youth emerged as polarised as the mainstream political parties they belonged to and were indistinguishable from those parties and their ethos.

What was lacking was the conglomeration of different classes of youth to form a national movement unified by similar objectives or, at least, a resolve to address the common problems of governance in the country.

High levels of poverty, unemployment and commodification of the electoral process by both politicians and the youth in the Zimbabwean context suggest that

[s]ocial structure is an interactive whole where the actions of individuals and minor groups play a role and 'realise' as well as transform structures. Youth are neither universally manipulated nor passive actors in a world designed by others but individuals who are trying to chart their own course. The dynamics of collective movement is incomplete without a realist perspective on individual agency.

Abbink 2005, p 9

As political parties and senior politicians used party structures to limit pressure by the youth for more inclusion, significant numbers of young people were motivated by the desire to resolve their grievances, not as a coordinated uniform movement, but as individuals.

This attitude was not peculiar to the youth, older citizens attended rallies and professed support for the parties that offered more material benefits. For instance, although people were largely forced to attend Zanu-PF rallies, many villagers 
who faced starvation attended the rallies addressed by Robert Mugabe in order to get food parcels that were handed out by Grace Mugabe. It can therefore be argued that partisan attachment in the July 2013 elections was not mainly driven by support for the policies represented by the parties but by the material benefits they offered.

\section{THE YOUTH FACTOR THAT NEVER WAS?}

The net effect of the youth on the 2013 elections is difficult to determine. As the results of the elections were announced, with Zanu-PF and Mugabe emerging as winners, both non-governmental organisations and the MDC-T disputed the results, alleging manipulation of the voters' roll, vote rigging, particularly on the special vote, and disenfranchisement of potential urban voters who failed to register during the two voter registration exercises.

In its preliminary report the ZESN argued that more than 750000 urban voters were missing from the voters' roll and that $304890(8.7 \%)$ voters who were on the voters' roll had been denied the right to vote. There were several reasons for this (ZHRC 2014, p 13), the major one being that they were attempting to vote in the wrong ward. The ZESN argues that 'while at $39 \%$ of rural polling stations ZESN observers reported more than 25 potential voters being turned away and not permitted to vote, at $82 \%$ of urban polling stations more than 25 potential voters were turned away and not permitted to vote' (ZESN 2013).

While there is no evidence to suggest that only the youth were affected, what these statistics do suggest is that more urban voters were affected than rural voters. In rural areas reports of significant proportions of voters needing assistance raised concerns that even literate people were intimidated and forced to request assistance as a means of proving that they voted for Zanu-PF. The ZESN (2013) argues that 'at $49 \%$ of rural polling stations more than 25 people were assisted to vote as opposed to only $5 \%$ of urban polling stations'. The ZHRC also raised concern about 'the large number of assisted voters as indicated by ZEC. It was reported that a total of 206901 (5.9\%) people were assisted to cast their votes' (ZHRC 2014, p 14). It can be argued that different methods of vote rigging were employed depending on whether or not people were voting in rural areas and whether or not they were likely to vote for Zanu-PF.

Before the 2013 elections the dominant view among civil society organisations was that the youth would be the game changers and would ultimately determine the winner. However, this turned out not to be the case because of manipulation of the voters' roll, poor voter education, flawed voter registration processes and the turning away of mostly urban voters from polling stations (Youth Forum 2013). The Election Resource Centre reiterated that due to the large number of 
urban voters who were turned away and the manipulation of the voters' roll, urban voters, particularly the youth, were disenfranchised, hence they declared that the election was not fair. However, what was consistent in all the reports was that there were few incidents of physical violence.

\section{CONCLUSION}

In the past the youth in Zimbabwe have played a significant role in mobilising and campaigning for their respective political parties to the extent that, in previous elections, particularly those in 2008, they committed atrocities at the behest of their political leaders. But the scenario in 2013 was different - despite isolated cases of violence, the youth were largely invisible.

The 2013 election also challenged the assumption that the youth are largely homogenous, collaborative and uniform in their grievances. It became clear that they are largely polarised, either with regard to political affiliation or on the basis of socio-economic status. The concerns and interests of unemployed youth and the way they participated in the elections differ from those of emerging middleclass youth who benefited from the economic stability during the course of the Government of National Unity and from those of the youth in the diaspora.

Within political parties a significant proportion of the youth contested the elections either as candidates for the National Assembly or through the proportional representation system. However, they faced significant structural challenges from their parties - the imposition of candidates, patronage and votebuying were prevalent in both Zanu-PF and the MDC-T. Young people who contested the elections found themselves struggling to raise financial resources to compete against senior politicians and were mainly posted to constituencies in which their parties had no chances of winning. They therefore continued to be structurally sidelined from active politics.

The differences in the socio-economic status of the youth, coupled with the commodification of political participation, hindered the effectiveness of youth initiated projects aimed at effective participation in the elections. Duplication of effort and activities targeted at the youth were largely tainted by a lack of transparency in the utilisation of donor funding, resulting in the extension of clientelism. As a result, youth participation in the 2013 elections was dominated by individual interests driven by the need to gain from material and financial goods distributed by political parties during the electoral period. Hence, although the youth attended political rallies, the number of registered youth voters remained lower than it is in other countries in the region. 


\section{- REFERENCES -}

Abbink, J. 2005. Being Young in Africa: The Politics of Despair and Renewal. Boston: Brill. ActionAid Denmark. 2013. Eager or Slumbering? Youth and Political Participation in Zimbabwe, May 2013. Available at: dipd.dk/wp-content/uploads/MS-report2013-Zimbabwe-Eager-or-Slumbering.pdf

African Union. 2006. African Youth Charter. Addis Ababa: African Union.

African Union. 2011. The African Youth Decade 2009-2018 Plan of Action. Addis Ababa: African Union.

African Union Commission. 2013. Report of African Union Election Observation Mission to the 31 July 2013 Harmonised Elections in the Republic Of Zimbabwe. Addis Ababa: African Union. Available at: pa.au.int/en/sites/default/files / AUEOM\% 20REPORT\%20ZIMBABWE\%202013.pdf

Amnesty International. 2013. Zimbabwe: Human Rights Agenda for the Government, 20132018. Available at: www.amnesty.org/en/library / asset/ AFR46/017 / 2013 / en/917d9a50-160f-42f2-b2e1-416ca20fcdc0 / afr460172013en.html

Browning, G, A Halcli \& F Webster. 2000. Understanding Contemporary Society: Theories of the Present. London: Sage.

COMESA. 2013. 'COMESA Election Observer Mission to the 31 July 2013 Harmonised Elections in the Republic Of Zimbabwe: Preliminary Statement.' Issued at Crowne Plaza Hotel, Harare, 3 August 2013. Available at: www. comesa.int $/$ index.php?option $=$ com_content\&view $=$ article\&id=826: come sa-election-observer-mission-to-the-31-july-2013-harmonised-elections-inthe-republic-of-zimbabwe\&catid $=6$ :press-releases\&Itemid $=57$

Daily News, The. 2013. 'Door-to-door campaign boils over', 17 May. Available at: www.dailynews.co.zw/articles / 2013/05/17/ door-to-door-camapign-boilsover

Durham, D. 2000. 'Youth and the Social Imagination in Africa: Introduction to Parts 1 and 2'. Anthropological Quarterly 73(3).

Fox News. 2013. 'Youth, rural voters may hold key to Zimbabwe election', 27 July. Available at: www.foxnews.com/world/2013/07/27/youth-rural-votersmay-hold-key-to-zimbabwe-election/

Government of Zimbabwe. 2013. Zimbabwe National Youth Policy, 2013. Available at: www.mydie.gov.zw/nyp pdf

Herald, The. 2011. 'Kasukuwere defends recruitment of youths', 21 March. Available at: www.herald.co.zw / kasukuwere-defends-recruitment-of-youths /

Hibou, B, H Meddeb \& H Mohammed. 2011. La Tunisie d'Apres le 14 Janvier et Son Economie Politique et Sociale. Copenhagen: Euro-Mediterranean Human Rights Network.

Hodgkinson, D. 2013. “The “Hardcore" Student Activist: The Zimbabwe National 
Students Union (ZINASU), State Violence, and Frustrated Masculinity, 2000-2008'. Journal of Southern African Studies 39(4).

Hodzi, O. 2013. 'One Step Forward, Two Steps Back: Constitution-Making and Voter Education in Zimbabwe'. Oxford Human Rights Hub, 24. Available at: ohrh.law.ox.ac.uk/?p=1816

Honwana, A M. 2012. The Time of Youth: Work, Social Change, and Politics in Africa. United States of America: Kumarian Press.

Honwana, A M. 2013. Youth and Revolution in Tunisia. London: Zed Books.

Kademaunga, M. 2011. 'Doomed Generation? Not if Zimbabwe's Youth Can Seize the Day'. OSISA. Available at: www.osisa.org/sites / default/files/sup_files / Youth\%20-\%20Doomed\%20generation.pdf

Kitschelt, H \& S I Wilkinson 2007. Patrons, Clients and Policies: Patterns of Democratic Accountability and Political Competition. Cambridge University Press.

Kuvirimirwa, F. 2013. 'Bogus online voters' roll'. The Herald, 4 July. Available at: www.herald.co.zw/ bogus-online-voters-roll/

Mahove, C. 2013. 'Madzore's candidature in Dzivarasekwa raises discord in MDC-T'. The Standard, 12 May. Available at: www.thestandard.co.zw/2013/05/12/ madzores-candidature-in-dzivarasekwa-raises-discord-in-mdc-t/

Masunungure, E. 2011. 'Zimbabwe at the Crossroads: Challenges for Civil Society'. OSISA. Available at: www.osisa.org/sites / default / files / sup_files / Zimbabwe $\% 20$ at $\% 20$ the $\% 20$ crossroads.pdf

McCandless, E. 2011, Polarization and Transformation in Zimbabwe: Social Movements, Strategy Dilemmas and Change. Rowman \& Littlefield.

Merz, T. 2013. 'Zimbabwe election: Twice as many registered voters as people in some areas'. The Telegraph, 31 July. Available at: www.telegraph.co.uk/ news / worldnews / africaandindianocean/ zimbabwe/10213352/Zimbabweelection-twice-as-many-registered-voters-as-people-in-some-areas.html

MISA-Zimbabwe. 2013. 'POTRAZ bans bulk SMS'. Kubatana.net, 26 July. Available at: www.kubatana.net/html/archive/media/130726misaz1. asp?sector $=$ INFTEC\&year $=0$ \&range_start $=1$

Monroe, K R \& K H Maher. 1995. 'Psychology and rational actor theory'. Political Psychology 16(1).

Movement for Democratic Change. 2011. Article 8(8.1) of the Constitution of the MDC. Available at: mdctsa.files.wordpress.com/2012/05/constitution-ofthe-mdc.pdf

Movement for Democratic Change-Tsvangirai (MDC-T). 2013. Election Manifesto 2013: A New Zimbabwe - The Time is Now. Available at: kubatana.net/docs/ polpar/mdc_election_manifesto_130707.pdf

Musavengana, T. 2011. 'Security Sector: No Transition without Transformation'. OSISA. Available at: www.osisa.org/sites/default/files/sup_files / 
Security $\% 20$ sector\%20in\%20Zimbabwe $\% 20-\%$ 20Takawira\%20Musavengana. pdf

Ndlovu, R. 2013. 'Zimbabwe diaspora watches elections from afar'. Mail \&Guardian, 26 July. Available at: mg.co.za/ article / 2013-07-26-00-diaspora-watches-pollfrom-afar

NewsDay. 2012a. 'Army recruits 4600 illegally', 14 June. Available at: www.newsday. co.zw / 2012/06/14/2012-06-14-army-recruits-4-600-illegally /

NewsDay. 2012b. 'Army raises eyebrows', 15 June. Available at: www.newsday. co.zw / 2012/05/15/2012-05-15-army-raises-eyebrows /

NewsDay. 2013. 'Nothing wrong with buying votes - Zanu PF', 1 February. Available at: www.newsday.co.zw/2013/02/01/ nothing-wrong-with-buying-voteszanu-pf/

Norris, P. 2004. Electoral Engineering: Voting Rules and Political Behaviour. Cambridge: Cambridge University Press.

Petracca, M P. 1991. 'The rational choice approach to politics: a challenge to democratic theory'. The Review of Politics 53(2).

Research and Advocacy Unit (RAU). 2013. An Audit of Zimbabwe's 2013 Voters' Roll. Available at: www.swradioafrica.com/Documents / Audit $\% 20$ of $\% 20 J u n e \% 20$ 2013\%20Voters\%20Roll\%2016\%20July\%202013.pdf

Scott, J. 2000. 'Rational Choice Theory'. In G Browning, A Halcli \& F Webster. Understanding Contemporary Society: Theories of the Present. London: Sage.

Transparency International Zimbabwe. 2013. 'EAF: Position Paper on the Zimbabwe Elections 2013'. Available at: www.transparency.org.zw/index.php/ctmenu-item-23 / ct-menu-item-25/149-eaf-position-paper-on-the-zimbabweelections-2013

United Nations. 2007. Young People's Transition to Adulthood: Progress and Challenges. New York: United Nations.

Wilkins, S. 2013. 'Ndira's Wake: Politics, Memory and Mobility among the Youth of Mabvuku-Tafara, Harare'. Journal of Southern African Studies 39(4).

World Bank. 2007. World Development Report: Development and the Next Generation. Washington, DC: World Bank.

World Food Program. 2012. 'Zimbabwe 2012 Facts and Figures. Available at: www. wfp org/sites / default/ files / Zim\%20Fact\%20Sheet $\% 2011 \% 20$ April $\% 202012$. pdf

Youth Forum. 2013. 'Post-Election Zimbabwe'. Available at: youthforumzim. org / index.php?option=com_content\&view=article\&id=203:post-electionzimbabwe\&catid=38:general-news

Zhangazha, W. 2013. 'Police ban political parties from door-to-door campaigns'. Zimbabwe Independent, 17 May. Available at: www.theindependent. co.zw / 2013 / 05 / 17 / police-ban-political-parties-from-door-to-doorcampaigns/ 
Zimbabwe African National Union-Patriotic Front. Article 23(187) of the Constitution of Zanu-PF. Available at: www.kubatana.net/docs/polpar/ zanupf_constitution_050630.pdf

Zimbabwe African National Union-Patriotic Front (Zanu-PF). 2013. Team ZanuPF 2013. Available at: www.kubatana.net/docs/polpar/zanupf_election_ manifesto_130705.pdf

ZESN. 2013a' 'ZEC should extend mobile voter registration'. Available at: www. theindependent.co.zw / 2013/07/12/ zec-should-extend-mobile-voterregistration-zesn/

Zimbabwe Election Support Network (ZESN). 2013b. Statement on end of voter registration. Available at: www.swradioafrica.com/zesn-statement-on-endof-voter-registration/

Zimbabwe Human Rights Commission (ZHRC). 2014. 'Zimbabwe Human Rights Commission Report on the 31 July Harmonised Elections in Zimbabwe'. Available at: zimassoc.files.wordpress.com/2014/01/ zhrc-report-on-31july-2013-elections.pdf

Zimbabwe Independent, The. 2013. 'ZEC Should Extend Mobile Voter Registration ZESN', 12 July 2013. Available at: www.theindependent.co.zw/2013/07/12/ zec-should-extend-mobile-voter-registration-zesn/

Zimbabwe Election Support Network (ZESN). 2013. 'Zimbabwe: 2013 Harmonised Elections Preliminary Statement', 10 August. Available at: www.shabka. org / 2013/08/10/ zimbabwe-election-support-network-2013-harmonisedelections-preliminary-statement/

Zimbabwe National Statistics Agency (ZimStats). 2012. Census 2012: Preliminary Report. Available at: unstats.un.org/unsd/demographic/sources/ census /2010_phc/Zimbabwe/ZWE_CensusPreliminary2012.pdf

Zimbabwean, The. 2012. 'Zanu "buys" the youth', 3 October. Available at: www. thezimbabwean.co/news/zimbabwe/61300/zanu-buys-the-youth.html.

\section{Interviews}

Maureen Kademaunga, Member of the MDC-T National Youth Assembly, 6 January 2013.

Gladys Hlatywayo, Executive Director of the Zimbabwe Civic Education Trust (ZIMCET), 19 December 2013. 